\title{
$\mathrm{BCY}$ 기반 고체산화물 연료전지의 내구성에 영향을 미치는 인자에 대한 연구
}

\author{
배선영 ${ }^{1} \cdot$ 박미영 $^{1} \cdot$ 이종규 ${ }^{2} \cdot$ 임형태 $^{1, *}$ \\ ${ }^{1}$ 창원대학교 신소재공학부 \\ ${ }^{2}$ 포항산업과학연구원 기후에너지연구그룹
}

\section{Effects of the Air Flow Rate and Electrolyte Thickness on the Durability of Yttria-doped Barium Cerate (BCY)-based Solid Oxide Fuel Cells}

\author{
Seon Yeong Bae ${ }^{1}$, Mi Young Park ${ }^{1}$, Jong Gyu Lee ${ }^{2}$, and Hyung-Tae Lim ${ }^{1, *}$ \\ ${ }^{I}$ School of Materials Science and Engineering, Changwon National University, Changwon 51140, Republic of Korea \\ ${ }^{2}$ Energy Research Group, Research Institute of Industrial Science \& Technology, Pohang 37673, Republic of Korea
}

\begin{abstract}
Anode-supported yttria-doped barium cerate (BCY) electrolyte cells are fabricated and durability tests are conducted as a function of the current density (cell voltage sign), air flow rate, and BCY electrolyte thickness. As the air flow rate increases and the current density decreases (from negative to positive cell voltage), the cell voltage drop rate is reduced during the constant current test. The thick $(18 \mu \mathrm{m})$ electrolyte cell exhibits relatively stable performance in comparison with the thin $(10 \mu \mathrm{m})$ electrolyte cell. Electrolyte/electrode delamination is not observed on the cells, even after the negative voltage operation, and this is attributed to sufficient electronic conduction inside the BCY electrolyte. Thus, the present work indicates that the durability of BCY-based cells can be improved with optimization of the air utilization and electrolyte thickness.
\end{abstract}

(Received September 20, 2016; Accepted November 18, 2016)

Keywords: solid oxide fuel cell, proton conductor, barium cerate, degradation mechanism

1. 서 론

고체산화물 연료전지 (solid oxide fuel cell)는 $800^{\circ} \mathrm{C}$ 이상 의 고온에서 작동하기 때문에 효율을 극대화 할 수 있지만 고 온에서의 열화 문제로 인해 장기 내구성 측면에서는 불리 할 수 있다. 이러한 이유로 최근에는 저온 $\left(<600{ }^{\circ} \mathrm{C}\right)$ 에서 작동할 수 있는 고체산화물 연료전지가 많은 주목을 받고 있는데 특 히 프로톤 전도성 페로브스카이트 산화물을 전해질로 적용 하기 위한 노력이 이루어져 왔다 [1-6]. 이 중 $\mathrm{BCY}$ (yttria-doped barium cerates)는 높은 이온전도성 때문에 많은 관심을 받고 있지만 수증기와 이산화탄소 분위기에서의 화 학적 불안정성 때문에 연료전지의 전해질 물질로 적용하는 데 한계가 있다고 알려져 있다 [4-13]. 이산화탄소 및 수증기 와 $\mathrm{BCY}$ 반응식은 아래 (1), (2)와 같이 나타낼 수 있다.

*Corresponding Author: Hyung-Tae Lim [Tel: +82-55-213-3716, E-mail: htaelim@changwon.ac.kr] Copyright (c) The Korean Institute of Metals and Materials

$$
\mathrm{BaCeO}_{3}+\mathrm{CO}_{2} \rightarrow \mathrm{BaCO}_{3}+\mathrm{CeO}_{2}
$$

$$
\mathrm{BaCeO}_{3}+\mathrm{H}_{2} \mathrm{O} \rightarrow \mathrm{Ba}(\mathrm{OH})_{2}+\mathrm{CeO}_{2}
$$

$\mathrm{BCY}$ 의 화학적 안정성에 대한 연구는 주로 파우더나 소결 된 샘플 레벨에서 이루어졌으며 [14-20] 실제 연료전지 작동 조건에서 전해질로서의 안정성에 대한 연구는 아직 부족하 다고 할 수 있다. 기존의 관련 연구논문을 분석하면, 연료전 지 구성 물질 및 작동 조건에 따라 제각기 다른 열화율을 보 인다는 것을 알 수 있는데 [21-24] 예를 들어 $\mathrm{Nd}_{2} \mathrm{NiO}_{4+\mathrm{d}}$ 양극 재를 사용한 $\mathrm{BCY}$ 셀은 낮은 전류 밀도 $\left(0.04-0.06 \mathrm{~A} / \mathrm{cm}^{2}\right)$ 로 1000 시간 이상 작동하였을 때 $0 \%$ 에 가까운 열화율을 나타 낸 반면 LSCF (La-Sr-Co-Fe oxide) 양극물질을 적용한 또 다 른 $\mathrm{BCY}$ 셀 테스트에서는 $700{ }^{\circ} \mathrm{C}$ 작동온도에서 온도전압 0.5 $\mathrm{V}$ 에 해당되는 높은 전류밀도로 작동하였을 때 상당한 열화 가 관찰되었다 [7,24]. 따라서 $\mathrm{BCY}$ 셀의 안정성은 연료전지 


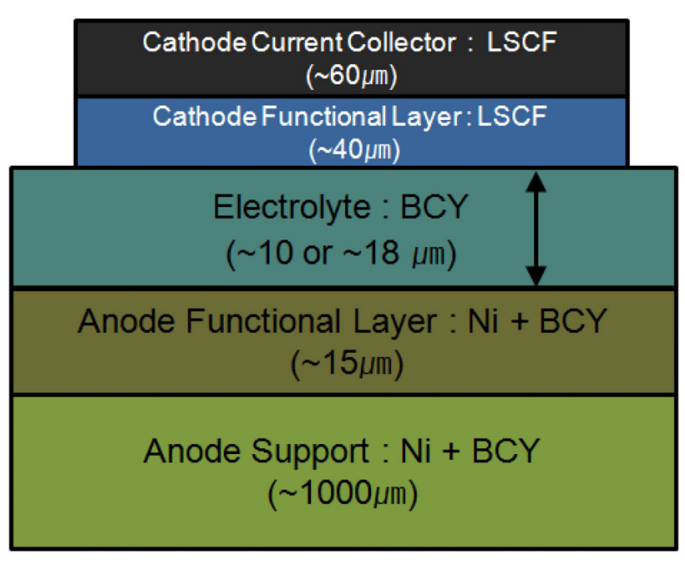

Fig. 1. A schematic of an anode supported cell (Ni-BCY/BCY/ LSCF-BCY)

셀 구성요소와 작동조건(e.g., 전류밀도, 온도)과 밀접한 관련 이 있으며, 이러한 요인들을 최적화 한다면 $\mathrm{BCY}$ 기반 연료 전지의 내구성을 개선할 수 있을 것으로 판단된다.

$\mathrm{BCY}$ 기반 셀의 스택 적용을 위해서는 역전압과 같은 가혹 한 작동환경에서의 내구성도 검증할 필요가 있다. 역전압 작 동은 직렬 스택의 Cell imbalance 현상(셀 간 성능편차)로 발 생할 수 있는 대표적인 연료전지 스택 열화 현상 중 하나이 다. 상대적으로 높은 저항을 가지는 불량 셀이 스택 내에서 역전압 작동을 하게 되면 전해질 내부 화학포텐셜의 증대로 인해 셀 전압 강하가 급격히 일어나게 되고 궁극적으로 물리 적 손상(전극 박리)을 일으키게 된다 [25]. 아래 식 (1)과 (2) 는 각각 $\mathrm{BCY}$ 와 같은 수소/산소 이온 혼합 전도체 전해질 내 부의 수소와 산소의 화학포텐셜 변화 (양극 계면 전해질 내부 에서 음극 계면 전해질 내부까지)를 나타낸 수식이다 [25-27].

$$
\begin{aligned}
& \Delta \mu_{H_{2}}=-2 e r_{H^{+}} I_{H^{+}}+2 e r_{e} I_{e} \\
& \Delta \mu_{O_{2}}=4 e r_{O^{2-}} I_{O^{2-}}-4 e r_{e} I_{e}
\end{aligned}
$$

위 식에서 $\mu_{H_{2}}, r_{H^{+}}$와 $I_{H^{+}}$는 각각 전해질 내부의 수소화학 포텐셜, 수소이온의 area specific resistance $\left(\Omega \mathrm{cm}^{2}\right)$ 와 수소이 온에 의한 전류밀도 $\left(\mathrm{A} / \mathrm{cm}^{2}\right)$ 를 뜻하며, $\mu_{O_{2}}, r_{O^{2-}}$ 와 $I_{O^{2-}}$ 는 각 각 전해질 내부의 산소화학포텐셜, 산소이온의 area specific resistance와 산소이온에 의한 전류밀도를 뜻한다. 또한 $e, r_{e}$ 와 $I_{e}$ 는 각각 기본전하량, 전해질 내부의 전자의 area specific resistance와 전자에 의한 전류밀도를 뜻한다. 정상 전압 (+전
압) 조건에서는 이온에 의한 전류밀도 $\left(I_{H^{+}}, I_{O^{2-}}\right)$ 는 음수이고, 전자에 의한 전류밀도 $\left(I_{e}\right)$ 는 양수이므로 식(1) 과 (2)로부터 전해질 내부 화학포텐셜의 변화는 정상 범위 내에서 예측가 능하다 $\left(\Delta \mu_{H_{2}}>0, \Delta \mu_{O_{2}}<0\right)$. 하지만 비정상 전압 (-전압) 조건에서는 이온에 의한 전류밀도는 여전히 음수이지만, 역 전압에 의해 전자에 의한 전류밀도도 음수가 되므로 식(1) 과 (2)로부터 전해질 내부 화학포텐셜 변화는 정상 범위를 벗어 날 수 있다 $\left(\Delta \mu_{H_{2}}>=<0, \Delta \mu_{O_{2}}>=<0\right)$. 즉, 셀 전압 부호에 따라 전해질 안정성이 크게 좌우됨을 알 수 있다.

전자전도성이 매우 낮은 YSZ(yttria stabilized zirconia)기 반 셀의 경우, 위에 기술한 열화 메커니즘과 같이 역전압 작 동환경에서는 비정상적으로 높은 산소 화학 포텐셜이 전해 질 내부에 형성되어 전극과 전해질 계면에 박리가 발생하는 것으로 보고된 바 있다 $[24,26]$. 반면에 BCY 기반 셀의 경우, 전극/전해질 계면과 가까운 전해질 영역에서는 전자/홀 전도 도가 충분하므로 역전압 작동 하에서도 내부 화학 포텐셜 상 승이 억제되어 박리현상은 발생하지 않을 것으로 예상된다 [26,27]. 본 연구에서는 음극 지지체형 $\mathrm{BCY}$ 전해질 셀을 제 조하여 전해질 두께 및 공기 유량을 변화하여 정전류 테스트 를 실시함으로써 $\mathrm{BCY}$ 열화율에 영향을 주는 요인들을 파악 하고자 하였다. 특히 역전압과 같은 가혹한 작동 조건에서 $\mathrm{BCY}$ 셀의 내구성을 알아보기 위해 정전류 테스트를 + 전압 뿐 아니라 - 전압에서 실시하였다.

\section{2. 실험방법}

본 연구에 사용된 $\mathrm{BCY}$ 기반 고체산화물 연료전지는 음극 지지체형이며, 반응 유효면적 (양극면적)은 $~ 1.54 \mathrm{~cm}^{2}$ 이다. 셀을 구성하는 5 개의 층은 그림 1 과 같이 음극 지지체 (anode support: $\mathrm{Ni}+\mathrm{BCY}$ ), 음극 기능층 (anode functional layer: $\mathrm{Ni}+\mathrm{BCY}, \mathrm{BaCe}_{0.85} \mathrm{Y}_{0.15} \mathrm{O}_{2.925}, 8.5 \mathrm{~m}^{2} \mathrm{~g}^{-1}$, Kceracell), 전해질층 (electrolyte: $\mathrm{BCY}$ ), 양극기능층 (cathode functional layer: $\mathrm{BCY}+\mathrm{LSFC}, \mathrm{La}_{0.6} \mathrm{Sr}_{0.4} \mathrm{Co}_{0.2} \mathrm{Fe}_{0.8} \mathrm{O}_{3-\mathrm{d}}, \mathrm{FCM}$ ), 양극 집전층 (cathode current collector: LSCF)으로 구분된다. 음극 지지체 구성, 음극 기능층, $\mathrm{BCY}$ 전해질 제조에 대한 자세한 설명은 해당 참고문헌에서 찾을 수 있다 [26]. 두께에 따른 내구성 변 화를 관찰하기 위하여 본 연구에서는 10 과 $18 \mu \mathrm{m}$ 두께의 $\mathrm{BCY}$ 전해질 셀을 제조하였으며 두께는 $\mathrm{BCY}$ slurry 코팅 양 으로 조절하였다. 접촉 저항 최소화를 위해 $\mathrm{Ni}$ mesh/Pt paste 와 $\mathrm{Ag} \mathrm{mesh} / \mathrm{Pt}$ paste를 각각 음극과 양극 표면에 적용하였으 


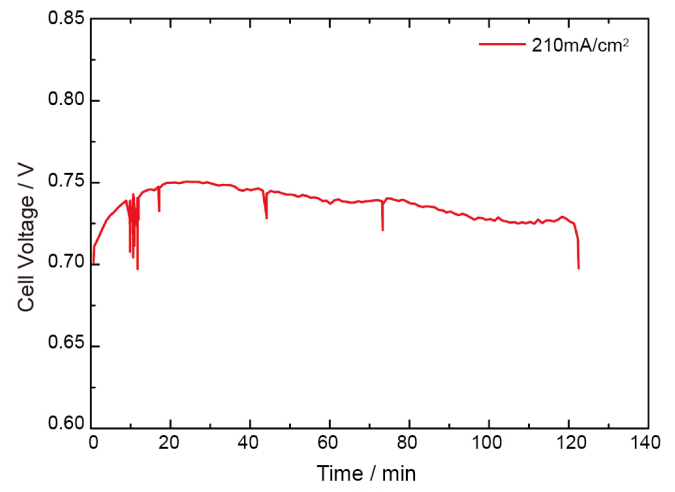

(a)

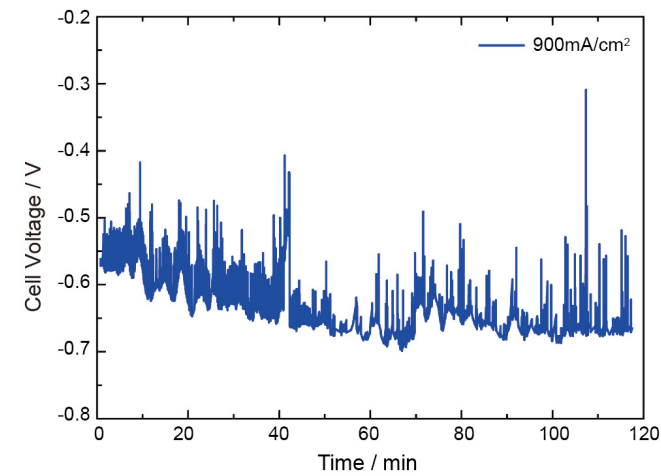

(b)

Fig. 2. Voltage plot vs. time under condition 1: (a) $210 \mathrm{~mA} / \mathrm{cm}^{2}$ and (b) $900 \mathrm{~mA} / \mathrm{cm}^{2}$

며 가스 밀봉을 위해서 mica gasket과 함께 특별히 디자인된 테스트 장치를 이용하였다. 셀 테스트를 위한 자세한 전 처리 과정은 참고문헌에서 찾을 수 있다 [26].

전기화학 성능 평가를 수행하기에 앞서 $10 \% \mathrm{H}_{2}$ 혼합가스 를 이용하여 $\mathrm{NiO}$ 환원을 실시하였으며, 그 후 음극과 양극에 각각 수소와 공기를 $200 \mathrm{ml} / \mathrm{min}$ 의 유량 조건으로 공급하여 개방회로전압 $(\mathrm{OCV})$ 를 확인하였다. 정전류(Constant Current) 테스트는 $600{ }^{\circ} \mathrm{C}$ 에서 전해질 두께 및 가스 유량을 변화하여 표 1 과 같은 세 가지 조건에서 실시하였다: 1) 10 $\mu \mathrm{m}$ 두께 전해질 및 수소 200 / 공기 $200 \mathrm{ml} / \mathrm{min}$ 유량, 2) 10 $\mu \mathrm{m}$ 두께 전해질 및 수소 200 / 공기 $1000 \mathrm{ml} / \mathrm{min}$ 유량, 3) 18 $\mu \mathrm{m}$ 두께 전해질 및 수소 200 / 공기 $200 \mathrm{ml} / \mathrm{min}$ 유량. 정전류 테스트는 $+0.7 \mathrm{~V}$ 과 $-0.2 \sim-0.5 \mathrm{~V}$ 수준에 해당되는 부하를 인가하였으며 정전류 테스트 전후 출력 및 임피던스를 측정 하여 성능 변화 요인을 분석하고자 하였다. 모든 전기화학테 스트는 BioLogic SP 240 potentiostat/galvanostat를 사용하여 수행하였다. 정전류 테스트 완료 후에는 SEM (Scanning electron microscopy)과 EDS (energy dispersive spectroscopy)를 이용하여 $\mathrm{BCY}$ 전해질 파단면의 미세구조
Table 1. Air flow rate and BCY electrolyte thickness for condition 1,2 and 3

\begin{tabular}{cccc}
\hline Thickness $(\mu \mathrm{m})$ & $\sim 10$ & $\sim 10$ & $\sim 18$ \\
\hline $\begin{array}{c}\text { Flow rate of } \\
\text { Hydrogen/Air } \\
(\mathrm{ml} / \mathrm{min})\end{array}$ & $200 / 200$ & $200 / 1000$ & $200 / 200$ \\
\hline
\end{tabular}

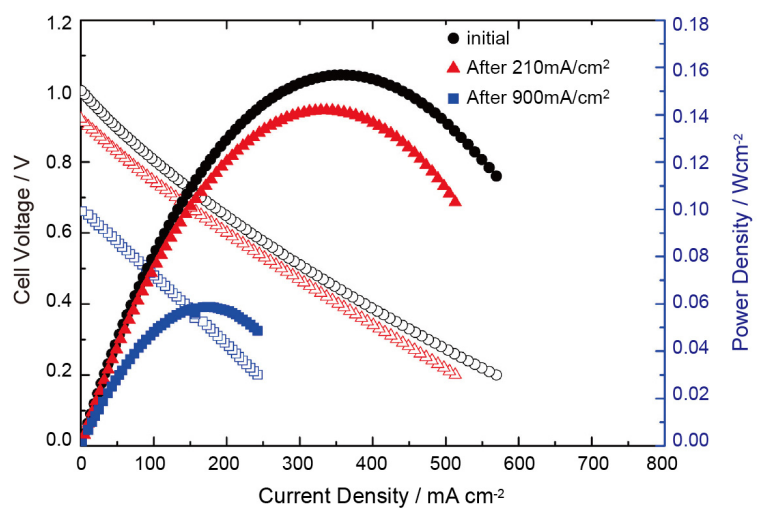

Fig. 3. Voltage current density and power density measured before and after the constant current tests under condition $1 \quad(\sim 10$ um, $\mathrm{H}_{2} \sim 200 \mathrm{ml} / \mathrm{min}$, Air $200 \mathrm{ml} / \mathrm{min}$ )

및 성분 분석을 실시하였다.

\section{3. 결과 및 고찰}

그림 2(a) 와 (b)에 조건 1에서 각각 $210 \mathrm{~mA} / \mathrm{cm}^{2}$ 와 900 $\mathrm{mA} / \mathrm{cm}^{2}$ 정전류 테스트 동안 시간에 따른 셀 전압 변화를 나 타내었다. $210 \mathrm{~mA} / \mathrm{cm}^{2}$ 정전류 테스트에서는 초기 $0.7 \mathrm{~V}$ 의 전압을 나타내었으며, 증가세를 보이다 점차 감소하였다. 2 시간의 정전류 테스트 동안 전압 강하 현상은 두드러지지는 않았지만 셀 전압이 안정적으로 유지되지는 않았음을 알 수 있다. (a) 테스트 종료 후 개방회로 상태로 전환하였으며 그 후 다시 $900 \mathrm{~mA} / \mathrm{cm}^{2}$ 에 해당되는 역 전압 테스트를 진행하 였다. 셀 전압은 초기 - $0.5 \mathrm{~V}$ 에서 시작하였으나 2 시간의 정 전류 테스트 동안 $-0.7 \mathrm{~V}$ 에서 $-0.3 \mathrm{~V}$ 까지 심한 변동을 보였 으며 전반적으로 전압 강하 현상이 이루어지고 있음을 알 수 있었다. 정 전류 테스트 전/후, 출력 특성 평가를 실시하였으 며 그림 3에 그 결과를 나타내었다. $+0.7 \mathrm{~V}$ 기준의 210 $\mathrm{mA} / \mathrm{cm}^{2}$ 정전류 테스트 후에는 개방회로 전압의 감소로 인해 출력 특성은 소폭 저하 되었지만 I-V curve 의 기울기 상으로 는 초기와 유사한 것으로 나타났다. 역전압, $-0.5 \mathrm{~V}$ 기준의 $900 \mathrm{~mA} / \mathrm{cm}^{2}$ 정전류 테스트 후에는 개방회로 전압이 큰 폭이 감소했을 뿐 아니라 셀 저항의 증가로 인해 최대 출력 값이 


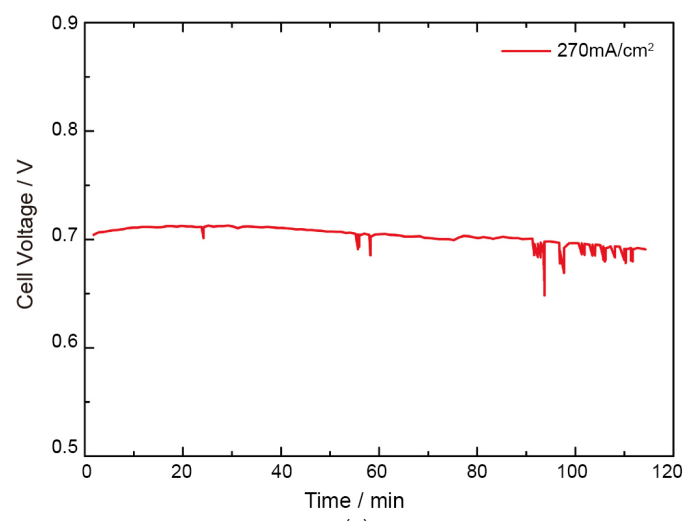

(a)

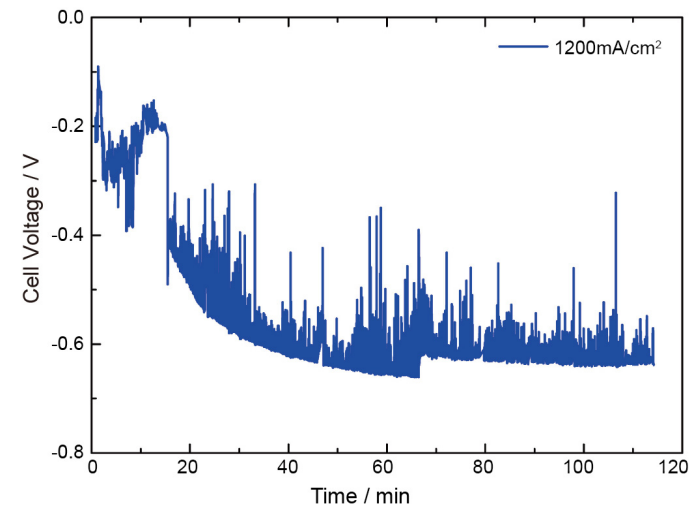

(b)

Fig. 4. Voltage plot vs. time under condition 2: (a) $270 \mathrm{~mA} / \mathrm{cm}^{2}$ and (b) $1200 \mathrm{~mA} / \mathrm{cm}^{2}$

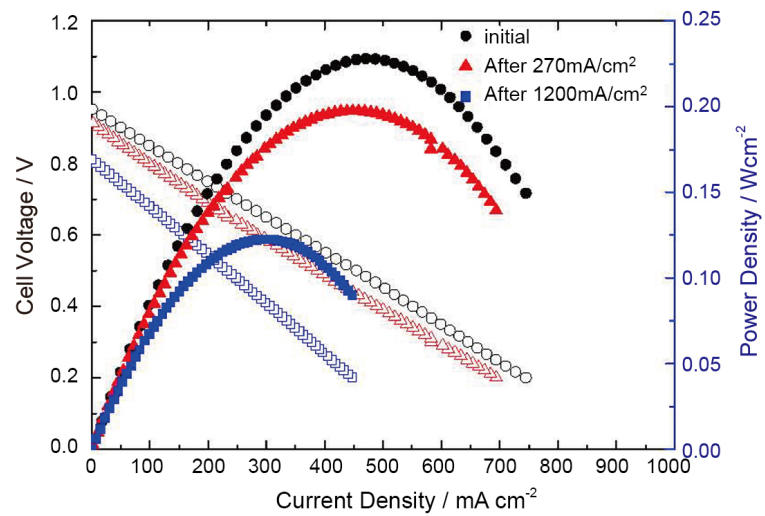

Fig. 5. Voltage current density and power density measured before and after the constant current tests under condition $2(\sim 10$ $\mu \mathrm{m}, \mathrm{H}_{2} \sim 200 \mathrm{ml} / \mathrm{min}$, Air $1000 \mathrm{ml} / \mathrm{min}$ )

초기 대비하여 $62.5 \%$ 감소하였다. 개방회로 전압이 감소하 였으므로 $900 \mathrm{~mA} / \mathrm{cm}^{2}$ 정전류 테스트 후에는 전해질의 상태 가 초기와는 많이 달라졌음을 유추할 수 있다. 그러므로 조건 1 과 같이 $200 / 200 \mathrm{ml} / \mathrm{min}$ 유량 공급 하의 얇은 $10 \mu \mathrm{m}$ 전해

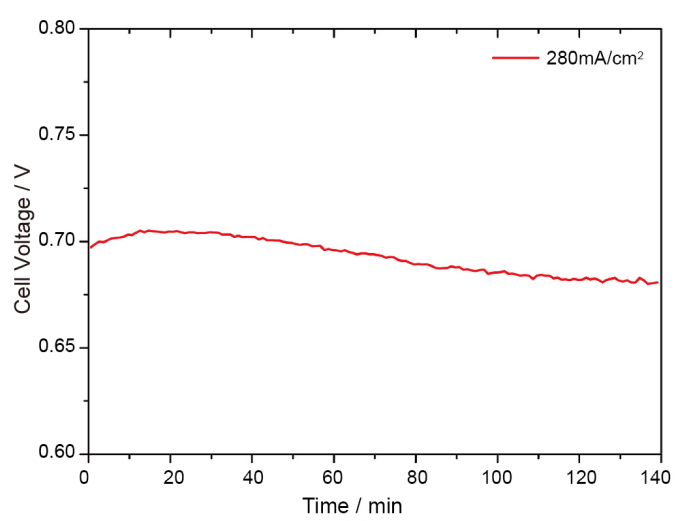

(a)

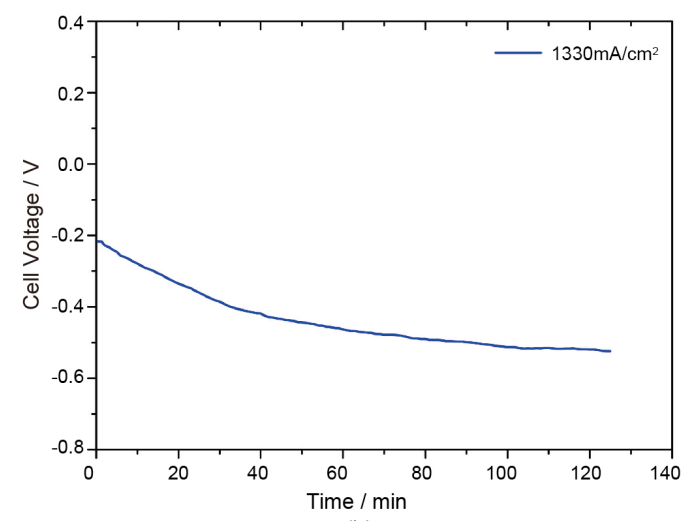

(b)

Fig. 6. Voltage plot vs. time under condition 3: (a) $280 \mathrm{~mA} / \mathrm{cm}^{2}$ and (b) $1330 \mathrm{~mA} / \mathrm{cm}^{2}$

질의 $\mathrm{BCY}$ 셀에서는 역전압에 이르는 높은 전류 조건일수록, 또한 주어진 공기 유량 대비 높은 전류 (높은 공기이용율) 조 건일수록, $\mathrm{BCY}$ 셀 열화율이 증대한다는 사실을 알 수 있다.

그림 4(a)는 $~ 10 \mu \mathrm{m}$ 두께 전해질에 분당 수소 $200 \mathrm{ml} / \mathrm{min}$ 및 공기 $1000 \mathrm{ml} / \mathrm{min}$ 를 공급하는 조건 2 에서 약 두 시간 동 안 $270 \mathrm{~mA} / \mathrm{cm}^{2}(0.7 \mathrm{~V})$ 정전류 테스트를 진행한 결과이다. 조 건 1 대비하여 공기 유량을 5 배 증가한 것 이외는 모든 조건 이 동일하다. 공기 유량 증가로 인해 조건 1에 대비하여 +0.7 $\mathrm{V}$ 에서 더 높은 전류 밀도 값을 나타내었으나, 전압강하 현상 은 완전히 개선되지 않았음을 알 수 있다. 그림 4(b)는 (a)에 이어서 역 전압(-0.2V) 하에서 $1200 \mathrm{~mA} / \mathrm{cm}^{2}$ 정전류 테스트 를 진행한 결과이며 초반의 급격한 전압 강하 이후 - $0.6 \sim$ $0.7 \mathrm{~V}$ 를 유지하는 것으로 나타났다. 조건 1 에서 진행한 바와 같이 정전류 테스트 전/후 출력 특성 평가를 진행하였으며 (그림 5) 초기 최대 출력 밀도 값은 공기 유량 증가로 인해 조 건 1 대비하여 $0.07 \mathrm{~W} / \mathrm{cm}^{2}$ 증가한 $0.23 \mathrm{~W} / \mathrm{cm}^{2}$ 로 측정되었 다. 공기 유량을 5 배로 증가시켜도 전류 값이 증가할수록 심 




Fig. 7. Voltage current density and power density measured before and after the constant current tests under condition $3(\sim 18$ um, $\mathrm{H}_{2} \sim 200 \mathrm{ml} / \mathrm{min}$, Air $200 \mathrm{ml} / \mathrm{min}$ )

화되는 열화 현상은 크게 개선될 수 없었지만 성능 감소율은 조건 1 대비하여 다소 완화되었음을 알 수 있다. 따라서 공기 유량을 증가시키면 출력밀도의 증가 뿐 아니라 열화율을 다 소 감소시켜 주는 효과가 있으며, 이러한 공기 유량과 $\mathrm{BCY}$ 셀 열화율과의 상관관계는 앞서 보고한 논문의 결과 (별도의 양극 가스 공급 없이 대기 가스를 이용했을 시 $\mathrm{BCY}$ 열화율 은 증대)와도 유사하다고 볼 수 있다 [28]. 다시 말해서, 양극 가스 (공기)이용율과 $\mathrm{BCY}$ 열화율은 반비례한다는 것이며, 전류값이 낮은 조건에서 공기 유량을 더욱 증대시킨다면 양 극 기능층 $(\mathrm{BCY} / \mathrm{LSCF}$ 복합체)의 $\mathrm{BCY}$ 삼상계면과 $\mathrm{BCY}$ 전 해질 계면에서의 생성되는 수증기의 몰 비율을 감소시켜 $\mathrm{BCY}$ 를 보호 할 수 있을 것이다.

전해질 두께와 열화율 간의 상관관계를 확인하기 위하여 전해질 두께를 2배로 증가하여 $18 \mu \mathrm{m} \mathrm{BCY}$ 전해질 셀을 제 조하였으며 조건 1과 동일한 유량 조건 (수소 $200 \mathrm{ml} / \mathrm{min}$ 및 공기 $200 \mathrm{ml} / \mathrm{min}$ 공급)으로 정전류 테스트를 진행하였다 (조 건 3). 먼저 $280 \mathrm{~mA} / \mathrm{cm}^{2}$ 정전류 테스트를 진행하였는데 전반 적으로 전압강하 현상이 나타났으나 조건 1 과 달리 전압이 불안정하게 흔들리는 현상은 관찰되지 않았다 (그림 6(a)). 이후 역 전압 조건이면서 고 전류 $\left(1330 \mathrm{~mA} / \mathrm{cm}^{2}\right)$ 에서 테스트 를 실시하였는데 초반 전압 강하가 이루어졌지만 후반으로 갈수록 감소율이 떨어지는 것으로 관찰되었다 (그림 6(b)). 그림 7과 같이 정전류 테스트 전/후 출력 테스트를 실시하였 는데 $280 \mathrm{~mA} / \mathrm{cm}^{2}$ 정전류 테스트 후 개방회로 전압이 다소 감소했음에도 불구하고 동등한 출력밀도를 유지하였으며, $1330 \mathrm{~mA} / \mathrm{cm}^{2}$ 의 고 전류 테스트 후 최대 출력 값은 초기 대 비 $30.7 \%$ 정도 감소하였다. 조건 1 대비 열화 특성은 개선되 었음을 알 수 있다. 이와 같은 결과로부터 $\mathrm{BCY}$ 전해질 두께

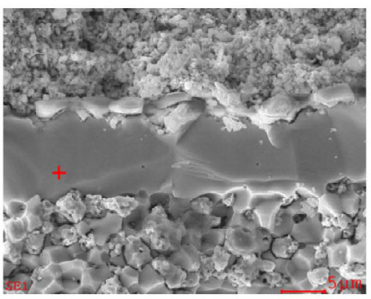

\begin{tabular}{|c|c|c|}
\hline Element & Weight $\%$ & Atomic\% \\
\hline$O$ & 10.90 & 48.65 \\
\hline $\mathrm{Y}$ & 02.00 & 01.74 \\
\hline $\mathrm{Ba}$ & 44.99 & 25.27 \\
\hline $\mathrm{Ce}$ & 41.98 & 23.11 \\
\hline
\end{tabular}

(a)



\begin{tabular}{|c|c|c|}
\hline Element & Weight\% & Atomic\% \\
\hline $\mathrm{O}$ & 17.45 & 63.41 \\
\hline $\mathrm{Y}$ & 04.63 & 03.02 \\
\hline $\mathrm{Ba}$ & 31.35 & 13.27 \\
\hline $\mathrm{Ce}$ & 44.88 & 18.62 \\
\hline
\end{tabular}

(b)

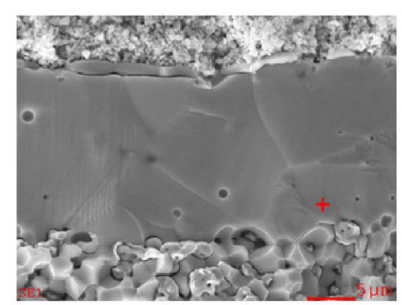

\begin{tabular}{|c|c|c|}
\hline Element & Weight\% & Atomic\% \\
\hline $\mathrm{O}$ & 11.54 & 52.05 \\
\hline $\mathrm{Y}$ & 02.14 & 01.74 \\
\hline $\mathrm{Ba}$ & 43.78 & 22.99 \\
\hline $\mathrm{Ce}$ & 40.69 & 20.95 \\
\hline
\end{tabular}

(c)

Fig. 8. SEM micrograph and EDS results of the cross section of the BCY electrolyte: (a) before the tests under condition 1, (b) after the tests under condition 1 and (c) after the tests under condition 3

와 $\mathrm{BCY}$ 셀 안정성 간 상관관계가 있다는 것을 알 수 있으며, 이는 앞서 보고한 전해질 내부 probe 를 이용한 $\mathrm{BCY}$ 전해질 내부 화학포텐셜 측정 연구논문으로부터 이해 할 수 있다 [29]. BCY 전해질 두께가 증가할수록 전해질 내부는 음극 쪽 분위기 (수소)에 더욱 지배를 받게 되고 수증기가 생성되는 양극 쪽 분위기 (산소 및 수증기)에서 멀어지게 되므로 수증 기에 의한 공격이 감소된다고 볼 수 있다. 이를 증명하기 위 하여 $~ 50 \mu \mathrm{m}$ 두께의 $\mathrm{BCY}$ 전해질 셀과 $\mathrm{BZY}+\mathrm{LSCF}$ 양극을 제조하여 본 연구와 유사한 정전류 테스트를 진행하였는데, 전압 강하는 관찰되지 않았다. 이번 연구에서는 $50 \mu \mathrm{m}$ 보다 얇은 전해질 $(\sim 18 \mu \mathrm{m})$ 이 사용되었고, 양극 물질도 $\mathrm{BZY}$ 가 아닌 $\mathrm{BCY}$ 를 포함하고 있기 때문에 어느 정도의 전압강하 현상은 관찰된 것으로 사료된다. 일반적으로 전해질 두께에 따라 ohmic 저항이 증가하여 셀 성능 (출력밀도)이 감소할 수 있지만, $\mathrm{BCY}$ 와 같이 (수증기) 분위기에 취약한 물질의 경 
우 내구성 향상 효과를 기대할 수 있다. 그림 3과 7의 초기 출 력밀도는 대등한 수준이므로 두께 증가로 인해 발생하는 성 능감소의 부정적 효과보다는 내구성 향상의 긍정적 효과가 더 우세하다고 할 수 있다.

정전류 테스트 종료 후 SEM 과 $\mathrm{EDS}$ 를 이용하여 전해질 층의 미세구조 및 성분 분석을 실시하였다. 그림 $8(\mathrm{a})$ 는 조건 1 에 해당되는 $10 \mu \mathrm{m}$ 두께의 $\mathrm{BCY}$ 전해질과 양극/음극 기능층 이 포함된 미세구조 사진이며, 테스트 전에 촬영되었다. 전해 질 단면을 $\mathrm{EDS}$ 성분 분석한 결과 $\mathrm{Ba} /(\mathrm{Ce}+\mathrm{Y})$ 의 atomic ratio 가 1.02 로 측정되어 소결 전의 $\mathrm{BCY}$ 분말(슬러리)조성과 유 사한 것으로 확인되었다. 그림 8(b)는 가장 높은 열화율을 보 였던 조건 1 테스트 후 미세구조 사진이며, 테스트 전인 (a)와 비교했을 때 미세구조 상 큰 차이가 있을 뿐 아니라 $\mathrm{Ba} /(\mathrm{Ce}+\mathrm{Y})$ atomic ratio 가 0.61 로 측정되어 초기 대비 $\mathrm{Ba}$ 이 전해질 내에 부족해 진 것으로 확인 되었다. 이는 $\mathrm{BCY}$ 가 정 전류 테스트 동안 양극에서 발생한 수증기에 의해 분해됨으 로써 나타난 결과로 이해할 수 있다 [28]. 그림 8(c)는 조건 3 ( $18 \mu \mathrm{m})$ 테스트 후의 $\mathrm{BCY}$ 전해질 분석결과로서 미세구조 뿐 아니라 $\mathrm{Ba} /(\mathrm{Ce}+\mathrm{Y})$ atomic ratio 도 테스트 전과 유사하여 가장 낮은 열화율을 보였던 조건 3 정전류 테스트 결과와 일 치한다고 할 수 있다. 단, (c) 분석 결과가 $\mathrm{BCY}$ 전해질 모든 영역을 대표하는 것은 아니므로 조건 3에서 발생한 열화 요 인을 정확히 파악하기 위해서는 $\mathrm{BCY}$ 전해질의 다른 영역이 나 양극 기능층에 포함된 $\mathrm{BCY}$ 입자를 추가 분석 할 필요가 있다. 또한 예상한 바와 같이 $\mathrm{BCY}$ 셀에서는 국부적 전자전 도성 때문에 역 전압 테스트 후 전극/전해질 계면 박리는 관 찰되지 않았다. 즉, $\mathrm{BCY}$ 셀의 열화 특성은 셀 전압 부호 (+ 또는 -)가 아닌 공기이용율과 같은 작동 조건에 크게 의존한 다고 볼 수 있다. 본 연구의 결과를 종합하자면, $\mathrm{BCY}$ 는 수증 기 분위기에 취약하여 연료전지 전해질로 적용하기에는 부 적합하다고 알려져 있지만 전해질 두께를 증대시키고 공기 이용율을 감소하는 등 수증기의 영향을 최소화 한다면 역전 압과 같은 작동 조건에서도 안정성을 크게 개선시킬 수 있을 것으로 판단된다.

\section{4. 결 론}

본 연구에서는 음극 지지체형 $\mathrm{BCY}$ 전해질 셀을 제조하여 전해질 두께 및 공기 유량을 변화하여 정전류 테스트를 실시 하였다. 특히 역전압과 같은 가혹한 작동 조건에서 $\mathrm{BCY}$ 셀 의 내구성을 알아보기 위해 정전류 테스트를 + 전압 뿐 아니
라 - 전압에서 실시하였다. 먼저 $10 \mu \mathrm{m}$ 두께의 $\mathrm{BCY}$ 전해질 셀의 경우 공기 유량을 증대 시킬수록 전류 값을 감소시킬수 록 (- 전압 보다는 + 전압 하에서) 셀 전압 강하는 완화되었는 데, 이로 부터 양극에서의 공기 이용율과 셀 내구성 간에 밀 접한 관계가 있다는 것을 이해할 수 있었다. 또한 전해질 두 께를 두 배로 증대시킨 $18 \mu \mathrm{m}$ 셀에서는 $~ 10 \mu \mathrm{m}$ 셀 보다 향 상된 열화특성을 나타내었으며 이는 $\mathrm{BCY}$ 전해질의 두께가 증대할수록 양극 분위기 (수증기 + 산소) 보다는 음극 분위기 (수소)에 더욱 지배를 받게 된다는 이전 연구결과와 일치 한 다. 또한 $\mathrm{BCY}$ 는 전해질/전극 계면의 상대적으로 높은 전자 전도성이 존재하므로 역전압 테스트 후에도 전해질/전극 박 리 현상은 관찰되지 않았다. 따라서 $\mathrm{BCY}$ 는 수증기 분위기 에 취약하여 연료전지 전해질로서 부적합하다고 알려져 있 지만 전해질의 두께를 증대시키고 공기 이용율을 감소하는 등 작동 환경을 최적화 한다면 역전압과 같은 가혹한 작동 조 건에서도 안정적인 작동을 기대할 수 있을 것이다.

\section{감사의 글}

본 연구는 2015년도 산업통상부의 재원으로 한국에너지 기술평가원(KETEP)의 지원을 받아 수행한 연구 과제입니 다.(No. 20143030031430 / No. 2015301030460 )

\section{REFERENCES}

1. H. G. Bohn, T. Schober, J. Am. Ceram. Soc. 83, 768 (2000).

2. K. Katahira, Y. Kohchi, T. Shimura, and H. Iwahara, Solid State Ion. 138, 91 (2000).

3. K. D. Kreuer, S. Adams, W. Munch, A. Fuchs, U. Klick, and J. Maier, Solid State Ion. 145, 295 (2001).

4. H. Iwahara, Solid State Ion. 77, 289 (1995).

5. H. Iwahara, Solid State Ion. 915, 86 (1996).

6. T. Norby, Solid State Ion. 125, 1 (1999).

7. J. Dailly and M. Marrony, J. Power Sources 240, 323 (2013).

8. T. Hibino, A. Hashimoto, M. Suzuki, and M. Sano, $J$. Electrochem. Soc. 149, A1503 (2002).

9. Z.-T. Tao, Z.-W. Zhu, H.-Q. Wang, and W. Liu, J. Power Sources 195, 3481 (2010).

10. X.-Z. Fu, J.-L. Luo, A.-R. Sanger, N. Luo, and K.-T. Chuang, J. Power Sources 195, 2659 (2010).

11. W. Suksamai and I.-S. Metcalfe, Solid State Ion. 178, 627 (2007).

12. T. Shimura, H. Tanaka, H. Matsumoto, and T. Yogo, Solid State Ion. 176, 2945 (2005).

13. K. Xie, R. Yan, X. Chen, S. Wang, Y. Jiang, X. Liu, and 
G. Meng, J. Alloy. Compd. 473, 323 (2009).

14. K. Katahira, Y. Kohchi, T. Shimura, and H. Iwahara, Solid State Ion. 138, 91 (2000).

15. J.-H. Kim, Y.-M. Kang, M.-S. Byun, K.-T. Hwang, Thin Solid Films 520, 1015 (2011).

16. N. Zakowsky, S. Williamson, J. T. S. Irvine, N. Zakowsky, S. Williamson, J. T. S. Irvine, Solid State Ion. 176, 3019 (2005).

17. C. W. Tanner and A. V. Virkar, J. Electrochem. Soc. 143, 1386 (1996).

18. Z. $\mathrm{Wu}$ and M. Liu, J. Electrochem. Soc. 144, 2170 (1997).

19. S. V. Bhide and A. V. Virkar, J. Electrochem. Soc. 146, 2038 (1999).

20. N. Taniguchi, C. Nishimura, and J. Kato, Solid State Ion. 145, 349 (2001).

21. G. Taillades, J. Dailly, M. Taillades-Jacquin, F. Mauvy, A. Essouhmi, M. Marrony, C. Lalanne, S. Fourcade, D. J.
Jones, J.-C. Grenier, and J. Rozièere, Fuel Cells 10, 166 (2010).

22. L. Zhao, B. He, Y. ling, Z. Xun, R. Peng, G. Meng, and X. Liu, Int. J. Hydrog. Energy 35, 3769 (2010).

23. L. Bi, S. Zhang, L. Zhang, Z. Tao, H. Wang, and W. Liu, Int. J. Hydrog. Energy 34, 2421 (2009).

24. F. Zhao and F. Chen, Int. J. Hydrog. Energy 35, 11194 (2010).

25. A. V. Virkar, J. Power Sources 172, 713 (2007).

26. M. G. Jung, Y. J. Kim, Y. G. Jung, and H.-T. Lim, Int. J. Hydrog. Energy 39, 16576 (2014).

27. M. Y. Park, H. Bae, and H.-T. Lim, J. Kor. Ceram. Soc. 51, 438 (2014).

28. M. Y. Park, Y. J. Kim, and H.-T. Lim, J. Ceram. Soc. Jpn. 123, 257 (2015).

29. M. Y. Park, M. G. Jung, S. Y. Bae, and H.-T. Lim, Electrochim. Acta 204, 183 (2016). 